\title{
Influence of Teachers' Experience on the Teaching of Technical Drawing in Technical Colleges in Edo and Delta States, Nigeria
}

\author{
Patrick Sunday Oyaimare Uddin ${ }^{1, ~ *, ~ S a m u e l ~ C h u k w u e m e k a ~ N w a c h o k o r ~}{ }^{2}$ \\ ${ }^{1}$ Department of Vocational and Technical Education, Ambrose Alli University, Ekpoma, Nigeria \\ ${ }^{2}$ Department of Computer and Robotics Education, University of Nigeria, Nsukka, Nigeria
}

Email address:

uddinpatrick@gmail.com (P. S. O. Uddin), samchokor $@$ gmail.com (S. C. Nwachokor)

${ }^{*}$ Corresponding author

\section{To cite this article:}

Patrick Sunday Oyaimare Uddin, Samuel Chukwuemeka Nwachokor. Influence of Teachers' Experience on the Teaching of Technical Drawing in Technical Colleges in Edo and Delta States, Nigeria. International Journal of Vocational Education and Training Research. Vol. 5, No. 1, 2019, pp. 38-42. doi: 10.11648/j.ijvetr.20190501.17

Received: May 15, 2019; Accepted: June 18, 2019; Published: July 11, 2019

\begin{abstract}
Technical drawing is the foundation for technical subject, it implies that it must be taught properly so that the students interest in any of the technical courses won't be dash to the ground. This study pointed out the value of an effective teacher and its importance to our educational system. Effectiveness of a teacher comes with updated experience of teacher to meet the demand of the $21^{\text {st }}$ century, instabilities of government policies causes more harm to our educational system. One research question was formulated and also a null hypothesis was used to test the level of significance at level of 0.05 . A structured questionnaire was developed and used for data collection. Copies of questionnaire were administered to 35 respondents to collect data. The data collected were analyzed using mean and standard deviation to answer the research questions and t- test statistics to test the null hypotheses. The findings of the study revealed that for a teacher to be effective in teaching he or she must have experience, but every teacher must update their experience acquired so as to meet up with the $21^{\text {st }}$ century. The study also recommended that seminars should be organized for teachers also there should be training and retraining of teachers so that they can meet up to the demand of teaching in the $21^{\text {st }}$ century.
\end{abstract}

Keywords: Technical Drawing, Pedagogical Profession, Teacher Behaviour, Teachers' Performance, Teacher Effectiveness

\section{Introduction}

A teacher's effectiveness relies on the level of the teacher's expectation on learning [1]. An effective teacher is one who is intellectually challenging and motivates students to learn [2]. Effective teachers are those teachers who achieved the goals set for them or goals set for them by others [3]. The four levels to determine if a teacher is effective are Instructional effectiveness, Uses of assessment for student learning, Positive learning environment and Personal quality of the teacher [4]. An effective teacher embraces complex concepts and topics in the curriculum doing everything possible for such concepts and topics to be meaningful to the students [1]. An effective teacher should know how, when and the type of assessment and feedback needed in his or her lesson [1]. Every effective teacher will always interact well with students both within and outside the classroom, thereby creating and maintaining a positive environment for learning [1]. An effective teacher is one who promotes good educational outcomes by organizing the class room and managing the behavior of the student to achieve this purpose [1]. Any teachers who cannot create a class room with positive cultures wit healthy interaction wouldn't be able to influence a student to achieve educational goals [5].

Experience is not just limited to various certificate acquired by teachers but also the knowledge on pedagogy. The content knowledge for pedagogy is sufficiently broad so that teachers can guide the development of their students as extensively as possible [6]. The teacher education is aimed at balancing teacher personal and professional competencies and building of experience [7]. Anyone whose dream is to end in the classroom as a teacher should have studied 
education as a major subject which will help in building various experience as one grows in the field [1].

Presently in Nigeria after graduating from the colleges of education with Nigeria Certificate in Education (NCE) or from the university with Bachelor in Education (B. Ed) students are licensed as teachers. The policy of Nigeria education system has contributed to the level of the educational standard, but the poor standard of teacher's education is attributed to instability of various government policies on education [8]. The lack of interest in the teaching profession has adverse effect on the present experience of teachers in our educational system. At present, willingness to take up a teaching appointment in government owned primary or secondary schools, is extremely low or poor. Some who opt for the offer, do so for monetary gains with few exceptions who are truly poised to teach and enhance students' performance. These experiences cannot meet up to the $21^{\text {st }}$ century demand to teach students [9]. The lack of interest in the teaching profession resulted from lack of motivation, improper recognition in term of salary and other incentive [10]. With the instability of government policies on education, institutions in Nigeria are now guilty of producing teachers that know nothing about the subject matter area and lack pedagogical skills [11]. This has push science teachers to teach sciences in abstraction because of the incompetence to deliver the knowledge of the subject matter [12].

Education is a very important human activity, it helps any society fashion and model individuals to function well in their environment [13]. Technical colleges are the main ground for teaching technical education. Technical education is the part of education considered to prepare individual for employment in specific area of occupation [14]. Technical education is not just an academic preparation but also a vocational preparation of students for jobs involving applied science and modern technology [14].

Among factors (quality of teaching, quality/qualification of teachers, teacher salary, in-service refresher courses and training etc.) influencing students' performance in technical drawing, teachers teaching experience is key. Teaching experience is the time spent by a teacher in the teaching profession. With the passage of time, teachers get command of their subjects and become competent in the art of teaching through experience. In other words, teaching experience improves the teaching skills and methodologies adopted [15]. Studies by $[16,17,18]$, document the importance of teachers' experience in student achievement. Each of these studies documented the improvement of student achievement with increase in teacher experience during the first three or five years of experience, with virtually no additional gains for experience beyond five years. Deductions from these studies is that novice teachers are less effective than teachers with some measure of experience. Nonetheless, beyond the first couple of years, more experienced teachers are no more effective than those with a couple of years of experience. This is so because there is little or no additional learning on the job by some teachers after first few years in teaching. Invariably, experience enhances teacher productivity at all grade levels, though experience effects decline as we progress from elementary to middle and high school. The bulk of the experience effects occur in the first year, with subsequent experience yielding diminishing increases in teacher productivity.

\subsection{Research Question}

What is the influence of teaching experience of technical drawing teachers on their effectiveness and academic achievement of students in technical drawing in Technical Colleges in Edo and Delta States?

\subsection{Hypothesis}

Ho1: There is no significant difference in teachers' effectiveness between the teachers with ten years and above teaching experience and teachers with less than ten years teaching experience in the teaching of technical drawing in technical colleges.

\section{Methodology}

The study adopted a survey research design. Survey research is the one, which involves the assessment of public opinion using questionnaire and sampling method [19]. The population of the study consisted of all Technical Drawing teachers in technical colleges of Edo and Delta States. There were 35 Technical Drawing teachers in the two states. All the 35 Technical Drawing teachers were used to respond to the questionnaire for classifying the teachers and they were also observed by the researcher for the classroom teaching observation. The instrument used for this study was called Teachers' Effectiveness Questionnaire (TEQ). The researcher used a four scale response which he scored as 1 point to Strongly Disagree (SD) 2 point to Disagree (D), 3 point to Agree (A) and 4 point to Strongly Agree (SA). Four points scale was used for the instruments. The mean cut-off point was 2.5. For the demographic information, Technical Drawing teachers who have spent ten years and above in the teaching field was regarded as 'experienced teacher' while Technical Drawing teachers who have spent below ten years in the teaching field was regarded as 'nor experienced teacher'. t-test of analysis was used to test all the hypotheses of this study.

\section{Discussion of Findings}

\subsection{Influence of Teachers' Experience on Teachers' Effectiveness}

Table 1 outlined the mean score and the standard deviation of the influence of above 10 years' experience and below 10 years' experience of technical drawing teachers on their effectiveness in the teaching of technical drawing. Table 1 reveals that teachers with above 10 years' experience had mean score above the 2.50 cut-off point in 11 variables of the 18 variables of teachers' effectiveness and had mean score less than the 2.50 cut-off points in seven variables. In other 
words, teachers with above 10 years' experience in teaching technical drawing were effective in 11 variables of teachers' effectiveness while they were not effective in seven variables. In the 11 variables of teachers' effectiveness where the technical drawing teachers were effective, the mean score range from 2.50 to 4.00 while in the variables of teachers' effectiveness where they were not effective, the mean score range from 2.15 to 2.40 . Also, Table 1 shows that teachers with below 10 years' experience in the teaching of technical drawing had mean score above the 2.50 cut-off point in seven variables out of the 18 variables of teachers' effectiveness and had less than 2.50 cut-off point in 11 variables. In other words, teachers with below 10 years' teaching experience in technical drawing teachers were effective in seven variables of teachers' effectiveness while they were not effective in 11 variables. In the seven variables of teachers' effectiveness where teachers with below 10 years' experience in technical drawing teachers were effective, the mean score range from 2.50 to 3.50 while among variables they were not effective, the mean score ranged from 1.60 to 2.40 . Table 1 further indicates that 25 out of 35 technical drawing teachers were above 10 years' experience while 10 technical drawing teachers were below 10 years' experience. Also, the overall mean score of 3.02 of the teachers with above 10 years' teaching experience is more than the 2.50 cut-off point which shows that they were effective while the overall mean score 2.25 of teachers below 10 years' experience in teaching technical drawing was less than the 2.50 cut-off point which indicates that they were not effective.

Table 1. Influence of teachers' experience on teachers' effectiveness.

\begin{tabular}{|c|c|c|c|c|c|c|c|}
\hline \multirow{2}{*}{$\mathbf{S} / \mathbf{N}$} & \multirow{2}{*}{ Variable of Teachers' Effectiveness } & \multicolumn{3}{|c|}{ Above 10 Years' Experience $n=25$} & \multicolumn{3}{|c|}{ Below 10 Years' Experience $n=10$} \\
\hline & & $\mathbf{x}$ & SD & Remark & $\mathbf{x}$ & SD & Remark \\
\hline 1 & Uses of variety of instructional strategies & 2.50 & 0.51 & $\mathrm{E}$ & 2.10 & 0.43 & $\mathrm{NE}$ \\
\hline 2 & Demonstrates patience, empathy and understanding & 2.40 & 0.49 & NE & 2.20 & 0.45 & NE \\
\hline 3 & Monitors students understanding and re-teaches & 4.00 & 0.80 & $\mathrm{E}$ & 2.40 & 0.49 & $\mathrm{NE}$ \\
\hline 4 & Provides practice and reviews for students & 2.40 & 0.49 & NE & 2.20 & 0.45 & NE \\
\hline 5 & Creates positive classroom environment & 4.00 & 0.82 & E & 2.60 & 0.53 & E \\
\hline 6 & $\begin{array}{l}\text { Assist students in discovering and correcting errors and } \\
\text { inaccuracy }\end{array}$ & 2.40 & 0.49 & $\mathrm{NE}$ & 2.10 & 0.43 & $\mathrm{NE}$ \\
\hline 7 & Teacher stimulates students' interest & 4.20 & 0.86 & $\mathrm{E}$ & 2.50 & 0.72 & $\mathrm{E}$ \\
\hline 8 & Uses variety of sensory materials & 2.40 & 0.49 & NE & 2.20 & 0.45 & NE \\
\hline 9 & Uses variety of cognitive levels in strategies of questioning & 2.72 & 0.56 & E & 2.50 & 0.51 & E \\
\hline 10 & Provides opportunities for successful experience by students & 3.50 & 0.72 & E & 2.50 & 0.51 & $\mathrm{E}$ \\
\hline 11 & Uses convergent and divergent inquiry strategies & 2.20 & 0.45 & NE & 2.10 & 0.43 & $\mathrm{NE}$ \\
\hline 12 & Demonstrates proper listening skills & 3.90 & 0.80 & E & 2.00 & 0.41 & NE \\
\hline 13 & $\begin{array}{l}\text { Maintains an environment in which students are actively } \\
\text { involved }\end{array}$ & 2.60 & 0.53 & $\mathrm{E}$ & 2.20 & 0.45 & NE \\
\hline 14 & Encourages students to ask questions & 3.80 & 0.78 & $\mathrm{E}$ & 1.60 & 0.33 & NE \\
\hline 15 & Provides positive feedback to students on their performance & 2.80 & 0.57 & $\mathrm{E}$ & 2.10 & 0.43 & NE \\
\hline 16 & Develops and demonstrate problem-solving skill & 2.15 & 0.44 & NE & 1.15 & 0.23 & NE \\
\hline 17 & Gives clear directions and explanations & 2.45 & 0.70 & NE & 2.05 & 0.42 & NE \\
\hline \multirow[t]{2}{*}{18} & $\begin{array}{l}\text { Implements an effective classroom management system for } \\
\text { positive behaviour }\end{array}$ & 4.01 & 0.82 & $\mathrm{E}$ & 3.01 & 0.61 & $\mathrm{E}$ \\
\hline & Overall Mean & 3.02 & 0.62 & $\mathrm{E}$ & 2.25 & 0.46 & $\mathrm{NE}$ \\
\hline
\end{tabular}

Note: E - Effective; NE - Not Effective.

\subsection{Teaching Experience of Technical Drawing Teachers and Students' Academic Achievement of Their Students}

Table 2 pointed out that students taught by technical drawing teachers with 10 years and above teaching experience had higher academic achievement with a mean score of 52.17 than students taught by technical drawing teachers with below 10 years teaching experiences with a mean score of 41.85.

Table 2. Teaching experience of technical drawing teachers and students academic achievement of their students.

\begin{tabular}{llll}
\hline Group & Teachers & Students & X \\
\hline 10 Years and Above & 25 & 300 & 52.17 \\
Below 10 Years & 10 & 300 & 41.85 \\
\hline
\end{tabular}

\subsection{T-test Analysis of Influence of Teachers' Experience on Teaching Effectiveness}

Table 3 outlined the t-test analysis of teachers' experience on teachers' effectiveness between teachers with above 10 years' teaching experience and those below 10 years' teaching experience in the teaching of technical drawing in technical colleges in Edo and Delta States of Nigeria. From Table 3, it is clearly seen that 5 out of 18 variables of teachers' effectiveness outlined a t-test calculated value less than the criterion value of 1.96 . Since each of the variables of teachers' effectiveness has ttest calculated values lower than the criterion value of 1.96 , the null hypothesis is retained. Therefore, there is no 
significant difference between teachers with above 10 years' teaching experience and those with below 10 years' teaching experience in the teaching of technical drawing in these technical colleges. In each of the other 13 variables of teachers' effectiveness the t-test calculated value is greater than the criterion value of 1.96. Since each of the variables of teachers' effectiveness has t-test calculated value greater than the criterion value of 1.96 , the null hypothesis is rejected. Therefore, there is significant difference between teachers with above 10 years' teaching experience and those with below 10 years' teaching experience in the teaching of technical drawing in these technical colleges.

Table 3. T-test analysis of influence of teachers' experience on teaching effectiveness.

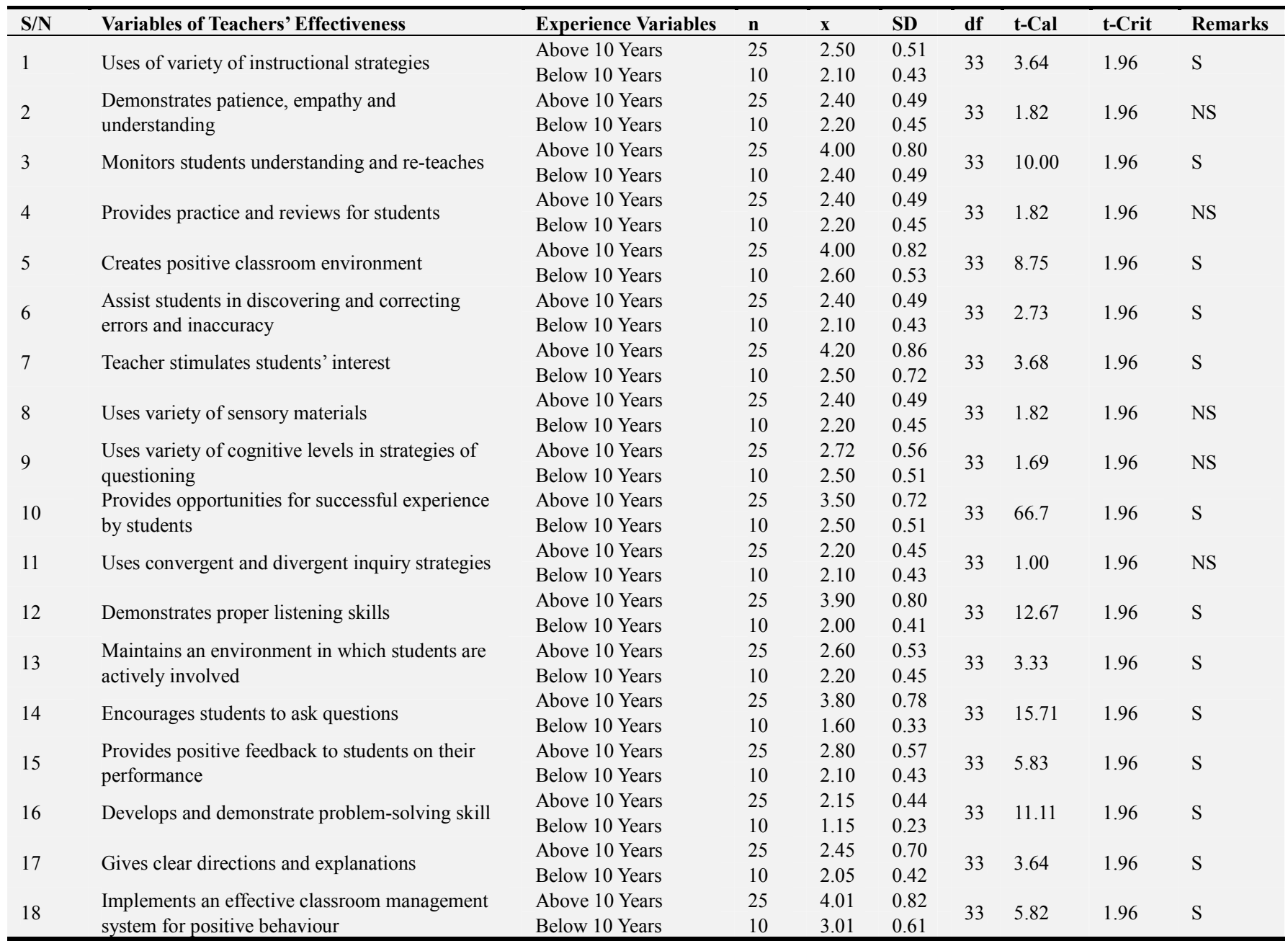

Note: S - Significant; NS - Not Significant.

\section{Conclusion}

The attainment of the goals of vocational and technical education is largely dependent on the depth of teachers' experience. For this, avenues should be created to boost teachers' knowledge, competencies and experiences through in-service training, conferences, seminars and workshops in a timely manner. This will enrich teachers' experience and help them stay up to date on recent trends in the field of technical drawing and help them gain mastery of the subject matter. More so, teacher recruitment should be done adhering to ideal standards in terms of quality and quantity, this will ensure students' benefit from the knowledge bank of their instructors without prejudice bearing in mind that vocational and technical education is not just an academic preparation but also a vocational preparation of students for jobs involving applied science and modern technology.

\section{References}

[1] Aina J. K. \& Ogundele A. G. (2015). The effectiveness of teachers in Finland: lessons for the Nigerian. Teachers American Journal of Social Sciences, 3 (5), 142-148.

[2] Darling-Hammond, L. (2010). Evaluating teacher effectiveness: How teacher performance assessments can measure and improve teaching. Washington DC: Center for American Progress.

[3] Anderson, L. W. (2004). Increasing teacher effectiveness. $2^{\text {nd }}$ Ed. Paris. International Institute for Educational Planning. 
[4] Stronge, J. H., Ward, T. J \&. L. W Grant, L. W. (2011). What Makes Good Teachers Good? A Cross-Case Analysis of the Connection between Teacher Effectiveness and Student Achievement. Journal of Teacher Education, 62 (4), 339.

[5] Nugent, T. T. (2009). The impact of teacher-student interaction on student motivation and achievement. Doctoral Thesis, University of Central Florida.

[6] Kansanen, P. (2003). Teacher education in Finland: current models and new developments. In M. Moon, L. Vlãsceanu \& C. Barrows (Eds.). Institutional approaches to teacher education within higher education in Europe: current models and new developments (pp. 85-108). Bucharest: UNESCOCEPES.

[7] Salhberg, P. (2010). The secret to Finland's success: educating teachers. Research Brief for Stanford Center for Opportunity Policy in Education. Accessed 17 June 2019. https://edpolicy.stanford.edu/sites/default/files/publications/se cret-finland $\% \mathrm{E} 2 \% 80 \% 99$ s-success-educating-teachers.pdf.

[8] Adelowokan, P. A, \& Makinde, F. B. (2010). Raising the poor standard of teacher education in Nigeria. South-West Journal of Teacher Education, 3 (1), 180-191.

[9] Adeoti, V. (2012, September 9) Challenges of Nigeria's education system. The Tide. $\mathrm{http}: / / w w w . t h e t i d e n e w s o n l i n e . c o m / 2012 / 09 / 09 /$ challengesofnigeria's-education-system/, accessed June 17, 2019.

[10] Akindutire, I. O \& Ekundayo, H. T. (2012) Teacher education in a democratic Nigeria: Challenges and the way forward. Educational Research, 3 (5), 429-435.

[11] Odia, L. O. \& Omofonmwan, S. I. (2007). Educational system in Nigeria problems and prospects Journal of Social Science, $14(1), 81-86$
[12] Abdullahi A. (2007). Functional science, technology and mathematics education for national economic empowerment and development. A Speech Delivered at the 2007 School of Science National Conference held at Federal College of Education, Zaria, April 2-5.

[13] Gerald, N. K., Augustine, M. K. A. \& Lucy W. N. (2013). Teacher factors influencing students' academic achievement in secondary schools in Nyandarua County, Kenya. International Journal of Education and Research, 1 (3), 1-14.

[14] Ogbuanya, T. C., Nweke, J. N. \& Ugwoke S. C. (2017). Material resource management for effective teaching of electrical/electronic technology in colleges of education (Technical) in Nigeria. International Journal of Applied Engineering Research, 12 (18), 7238-7253.

[15] Ezeji, S. C. O. A. (2001). Basic Principles of Research in Education. Enugu: Cheston Agency Ltd.

[16] Omorogbe, E. \& Ewansiha, J. C. (2013). The challenge of effective science teaching in Nigerian secondary schools. Academic Journal of Interdisciplinary Studies, 2 (7), 181-188. Doi: 10.5901/ajis.2013.v2n7p181.

[17] Rivkin, S. G., Hanushek, E. \& Kain, J. F. (2005). Teachers, schools and academic achievement. Econometrica, 73 (2), 415-458.

[18] Rockoff, J. E. (2004). The impact of individual teachers on student achievement: Evidence from panel data. American Economic Review, 94 (2), 247-252.

[19] Sanders, W. L., Ashton, J. J. \& Wright, W. P. (2005). Comparison of the effects of NBPTS certified teachers with other teachers on the rate of student academic progress. Report by the SAS Institute to the National Board on Professional Teaching Standards, Arlington, V. A. 